Supporting Information 


\section{Complementary electrolyte design for Li metal batteries in electric vehicle applications}

Meinan He, ${ }^{a \dagger}$ Chi-Cheung Su, ${ }^{\text {b }}$ Fan Xu,${ }^{a}$ Khalil Amine, ${ }^{\text {b,c }}$ and Mei Cai ${ }^{a^{*}}$

a General Motors Global Research and Development Center, 30500 Mound Road, Warren, MI, 48090 USA

${ }^{\mathrm{b}}$ Chemical Sciences and Engineering Division, Argonne National Laboratory, 9700 S. Cass

Avenue, Lemont, IL 60439, USA

${ }^{\mathrm{c}}$ Material Science and Engineering, Stanford University, Stanford, CA 94305, USA

$\dagger$ These authors contributed equally to this work.

*E-mail: mei.cai@gm.com

\section{EXPERIMENTAL}

Electrode preparation: The positive electrode composition was 96 wt.\% NMC622 from BASF, 2 wt.\% carbon black (Super P), and 2 wt.\% polyvinylidene fluoride (PVDF). The areal loading of the electrode was $25 \mathrm{mg} / \mathrm{cm}^{2}\left(4.5 \mathrm{mAh} / \mathrm{cm}^{2}\right)$ after calendaring to $25 \%$ porosity. The negative electrode was 20 or $30 \mu \mathrm{m} \mathrm{Li} \mathrm{metal} \mathrm{foil} \mathrm{on} \mathrm{a} \mathrm{Cu} \mathrm{current} \mathrm{collector}$ purchased from Kisco.

Electrolyte preparation: The electrolytes were prepared to follow the formulation disclosed in this report. All of the salts and solvents were purchase from $3^{\text {rd }}$ party vendors and further purified in the lab to battery electrolyte degree. The electrolyte preparation was performed in an Ar-filled glovebox with controlled moisture content $<2 \mathrm{ppm}$. 
Coin cell preparation: A 2032 type coin cell was used for battery testing. Li\|CCu, Li||Al, and $\mathrm{Li} \| \mathrm{NMC}$ cells were assembled in the Ar-filled glovebox with $\mathrm{Li}$ metal foil on a $\mathrm{Cu}$ current collector as both the counter and reference electrodes. Celgard ${ }^{\circledR}$ C210, microporous polypropylene/polyethylene/polypropylene (PP/PE/PP), was used as the separator. Al-clad coin cell cathode caps (Hohsen) were used instead of stainless cathode caps to avoid corrosion of the stainless at high voltage. The effective diameters of cathode, anode, and separator were $14 \mathrm{~mm}, 15 \mathrm{~mm}$, and $16 \mathrm{~mm}$, respectively.

Battery Test: Conductivity measurements of the electrolyte were carried out by using a conductivity cell (Cole-Parmer). The conductivity cell was calibrated using standard $\mathrm{KCl}$ solutions. The conductivities were measured using electrochemical impedance spectroscopy from $10 \mathrm{~Hz}$ to $1 \mathrm{MHz}$ with a $6 \mathrm{mV}$ perturbation voltage using a potentiostat (Bio-Logic). The impedance spectra were obtained using a Bio-Logic VMP3 electrochemical working station operated between $0.01 \mathrm{~Hz}$ and $1 \mathrm{MHz}$ with the amplitude of $10 \mathrm{mV}$.

The charge-discharge cycling performances of the 2032 coin cells were recorded using a MACCOR Electrochemical Analyzer at $25^{\circ} \mathrm{C}$ in environmental chambers. A two-cycle formation was performed with a rate of $\mathrm{C} / 10$ between 2.5 and $4.3 \mathrm{~V}$, followed by 250 cycles at a rate of $0.2 \mathrm{C}$ charge and $0.5 \mathrm{C}$ discharge between 2.5 and $4.3 \mathrm{~V}$.

The $\mathrm{Cu}$ foil used in this experiment was soaked in $1 \mathrm{M} \mathrm{H}_{2} \mathrm{SO}_{4}$ for 4 days to remove all of the $\mathrm{CuO}$ on the surface before washing with ethanol and acetone. The clean $\mathrm{Cu}$ foil was quickly transferred into an Ar-atmosphere glovebox after washing with acetone. The effective area of the Cu foil for $\mathrm{Li}$ deposition was $0.97 \mathrm{~cm}^{2}$, and the volume of electrolyte used in each coin cell was $40 \mu \mathrm{L}$. For the cycling test (Coulombic efficiency test), 
$4 \mathrm{mAh} / \mathrm{cm}^{2}$ of lithium was deposited on the Cu foil at $0.1 \mathrm{~mA} / \mathrm{cm}^{2}$ current density, and then plating and stripping were performed at $1 \mathrm{~mA} / \mathrm{cm}^{2}$ for 9 cycles before stripping all the lithium at $0.1 \mathrm{~mA} / \mathrm{cm}^{2}$ until the cell potential reached $1 \mathrm{~V}$. Cyclic voltammetry $(\mathrm{CV})$ on the Li/Cu cell was performed with a Solartron analyzer at a fixed scan rate of $1 \mathrm{mV} / \mathrm{s}$. The voltage range was $-200 \mathrm{mV}$ to $200 \mathrm{mV}$ over 10 cycles. The exchange current density was calculated by using a linear fit of Tafel plots ( $70 \mathrm{mV}$ to $100 \mathrm{mV}$ region) on the $10^{\text {th }}$ cycle so that a relatively stable solid-electrolyte interphase (SEI) could be formed.

Cell Disassembly and Scanning Electron Microscopy Analysis: The cycled cells were disassembled in an Ar-filled glovebox. The electrodes were thoroughly rinsed with anhydrous dimethyl carbonate and dried in a vacuum oven. The morphologies of the harvested electrodes were examined with scanning electron microscopy (SEM) using a Hitachi S-4800-II microscope.

NMR Quantitative Analysis: To quantitatively analyze the harvested electrolyte in a Li||NMC cell by nuclear magnetic resonance (NMR) spectroscopy, a standard solution with internal reference fluorobenzene (FB) was first prepared. In a $5 \mathrm{~mL}$ volumetric flask inside a glovebox under argon atmosphere, a small amount of FB $(0.0148 \mathrm{~g})$ was weighed. Acetonitrile- $d_{3}$ was then added to the flask to prepare a $5 \mathrm{~mL}$ solution, and the overall weight $(4.5116 \mathrm{~g})$ of the solution was also measured. A measured amount of the solution $(2.2501 \mathrm{~g})$ was then added to a dry vial inside the glovebox. The cycled Li/NMC coin cell was first washed with Dimethyl Carbonate (DMC) three times and vacuum dried before being dismantled in a Hohsen decrimper. All parts of the dismantled cell were then transferred quickly into the vial with the standard solution with $2.2501 \mathrm{~g} \mathrm{FB}$ in acetonitrile$d_{3}$. The capped vial was then shaken vigorously for 1 minute to ensure the dissolution of 
the electrolyte. After that, the solution was partially transferred to a NMR tube for quantitative analysis. The amounts of FEC and EMC left in the cycled cells were calculated by comparing the integration of the proton peaks of FB and the peaks of FEC or EMC.

The NMR analyses were carried out on a $300-\mathrm{MHz}$ NMR spectrometer. Deuterated benzene was placed in an external coaxial insert and then in the NMR tube with the samples. The ${ }^{1} \mathrm{H}$ chemical shifts were referenced to benzene- $d_{6}$ at $7.16 \mathrm{ppm}$. The spin lattice relaxation time $\left(T_{1}\right)$ was measured by the inversion recovery method. The relaxation delay time $\left(d_{1}\right)$ of the acquisition was larger than $5 T_{1}$ time.

X-ray photoelectron spectroscopy: XPS was performed using a Kratos Axis Ultra XPS, with a monochromatic Al source. The XPS curves were analyzed with Casa XPS software. The $\mathrm{C} 1 \mathrm{~s}$ peak at $284.5 \mathrm{eV}$ was used to calibrate the energies. 

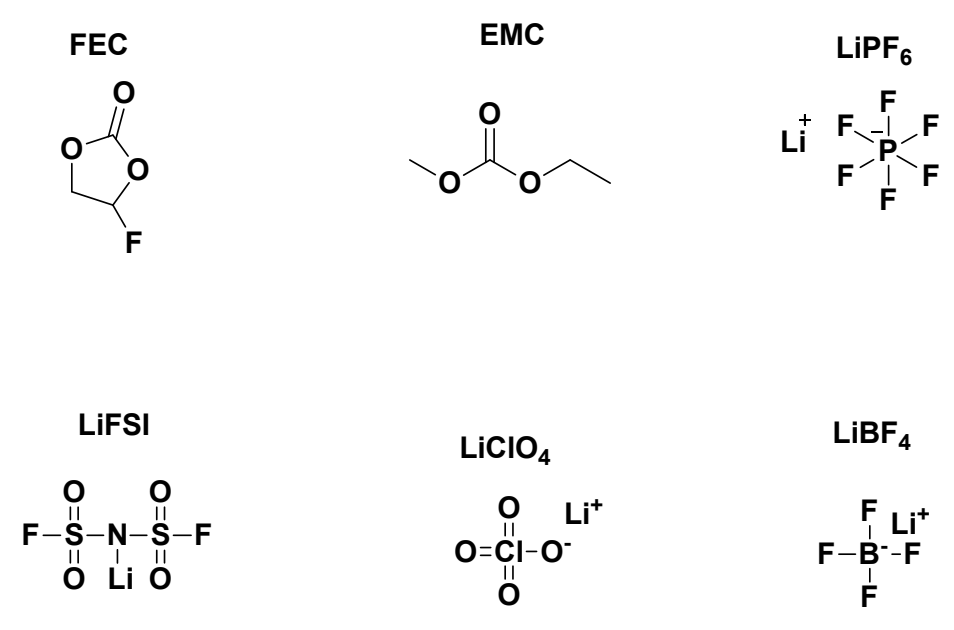

Figure S1. Chemical structures and acronyms of carbonates, fluorinated carbonates and lithium salts employed in this study.

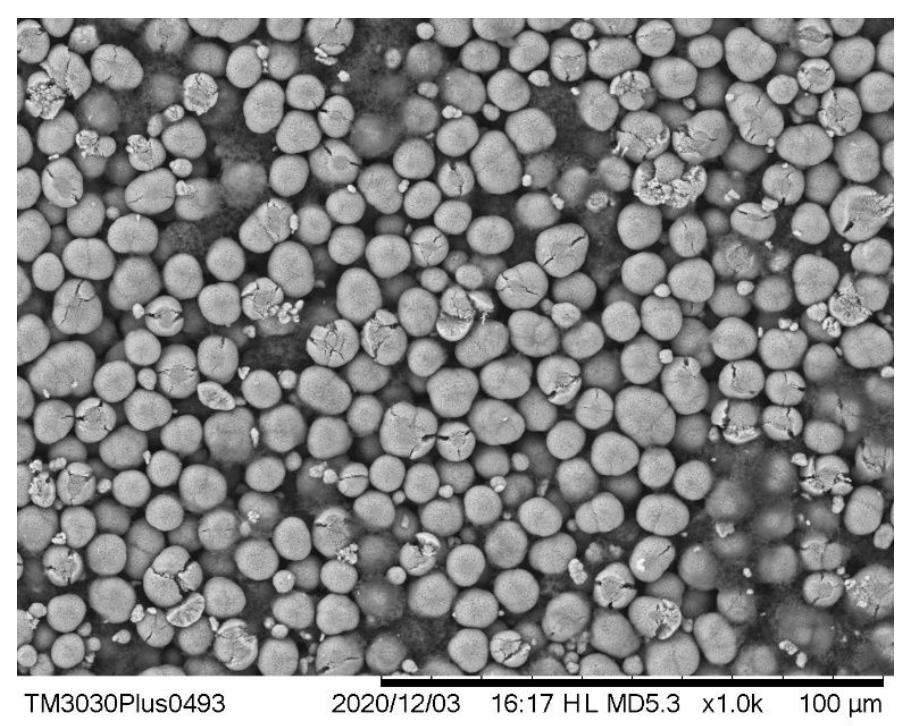

Figure S2. Pristine NMC622 cathode used in this study. The capacity area loading is about $4.5 \mathrm{mAh} / \mathrm{cm}^{2}$, while the active material loading is $25 \mathrm{mg} / \mathrm{cm}^{2}$. 

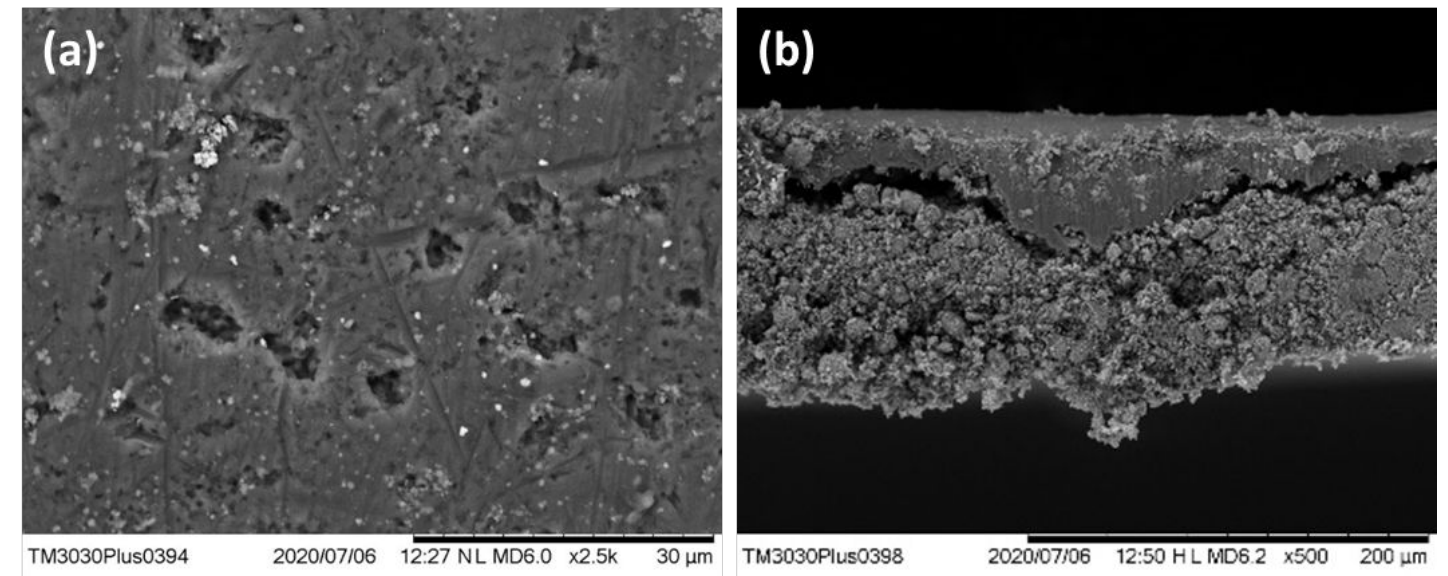

Figure S3(a). The backside (Al current collector) of the harvested electrode aged in LiFSI/FEC/EMC electrolyte. (b).Cross-sectional views of the harvested cathode after formation in $\mathrm{FEC} / \mathrm{EMC}=1 / 4(\mathrm{v} / \mathrm{v})$ electrolytes with $1 \mathrm{M} \mathrm{LiFSI}$ electrolyte.
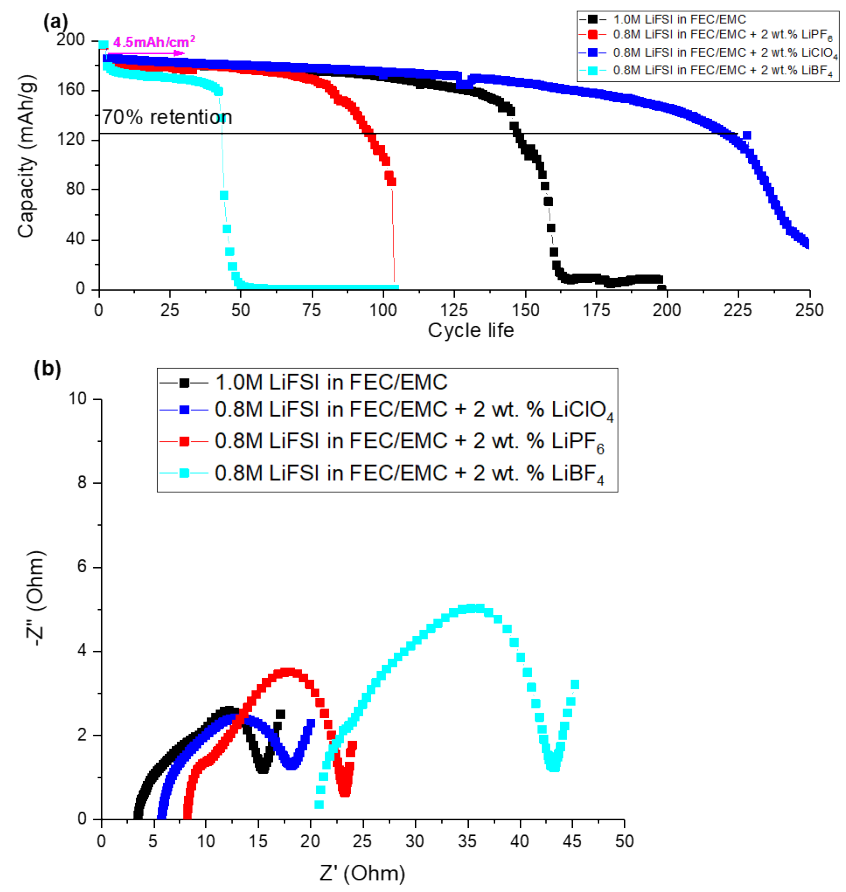
Figure S4. (a) Capacity retention and (b) electrochemical impedance spectra of Li/NMC622 cells with FEC/EMC electrolyte by using $1 \mathrm{M} \mathrm{LiFSI}, 0.8 \mathrm{M}$ LiFSI with 2 wt.\% $\mathrm{LiPF}_{6}, 2$ wt. $\% \mathrm{LiClO}_{4}$, and 2 wt.\% $\mathrm{LiBF}_{4}$ as additive.

(a)

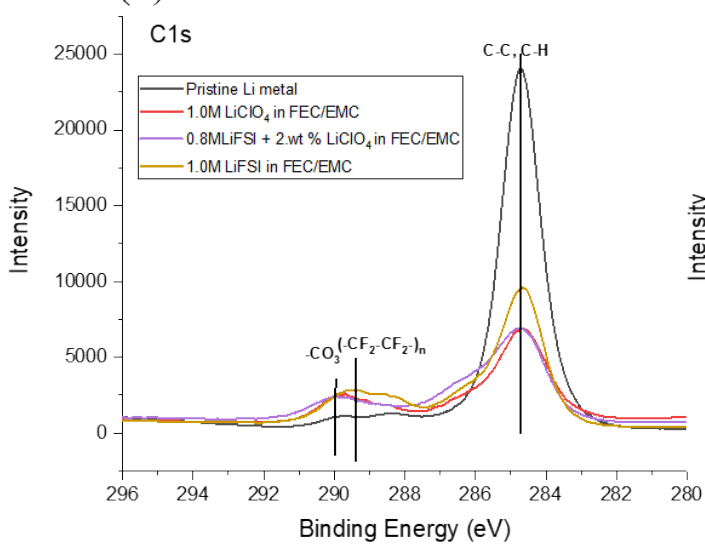

(c)

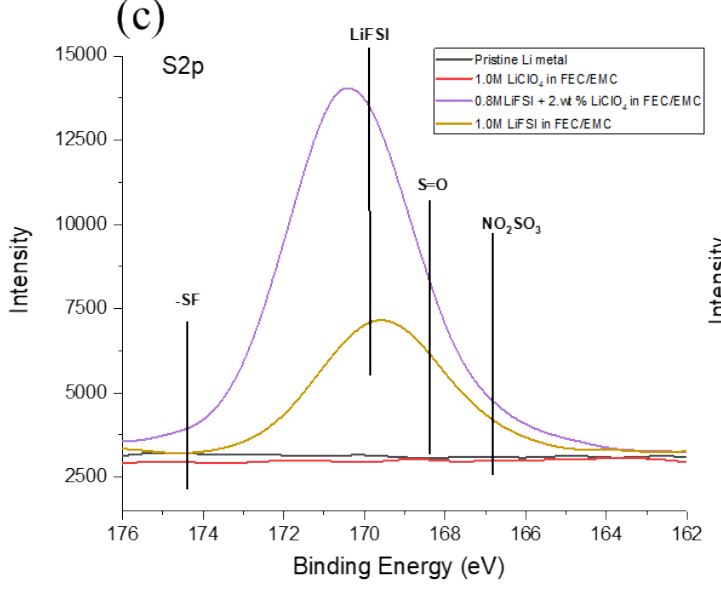

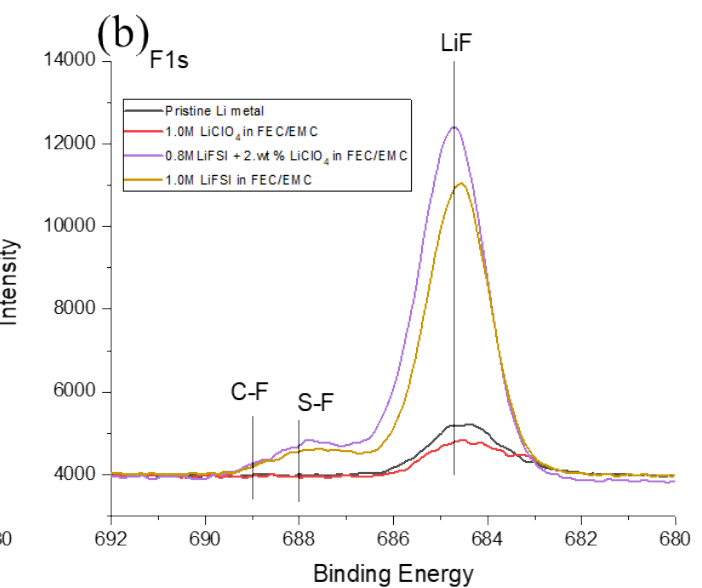

(d)

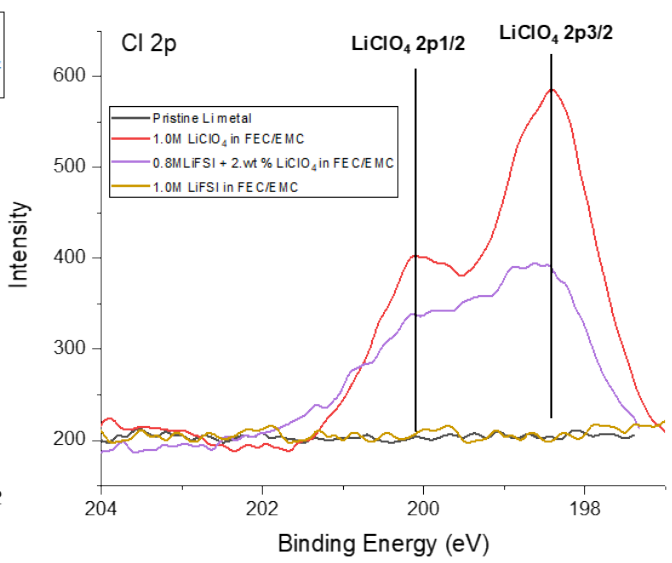

Figure S5. The XPS spectra of (a) C1s, (b) F1s, (c) S2p and (d) Cl2p for the pristine and harvested lithium anodes after formation under different electrolytes. 


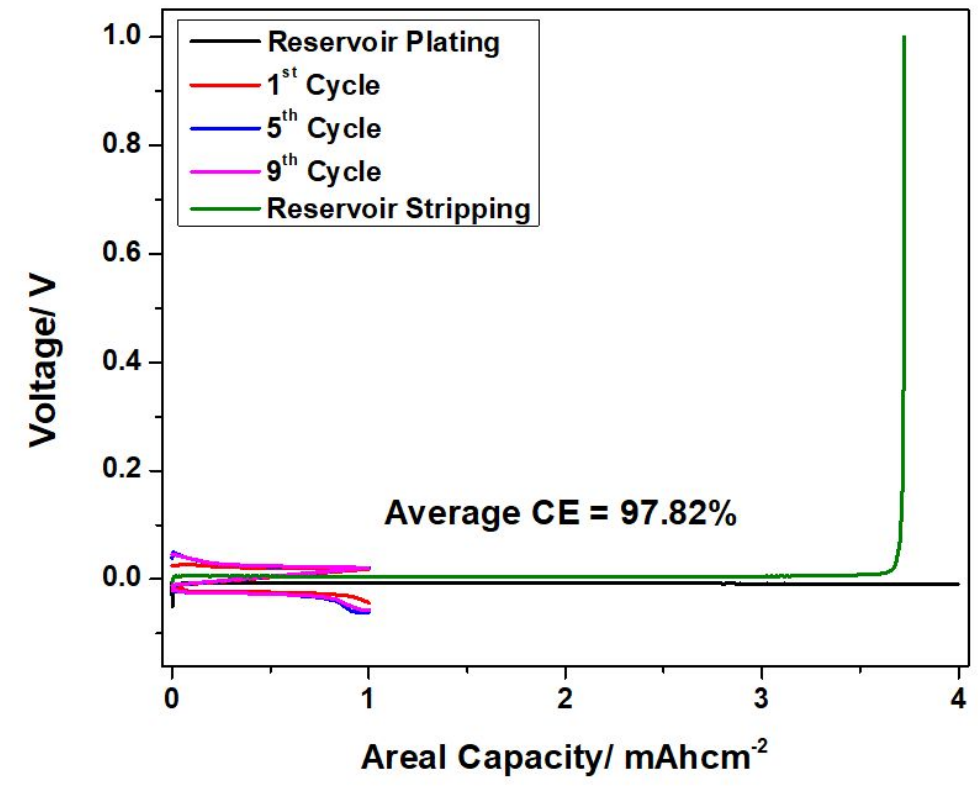

Figure S6. Voltage profile of Li plating/striping using $\mathrm{Li} / \mathrm{Cu}$ cell with $1 \mathrm{M} \mathrm{LiClO}_{4}$ plus $1 / 4$ (v/v) FEC/EMC.
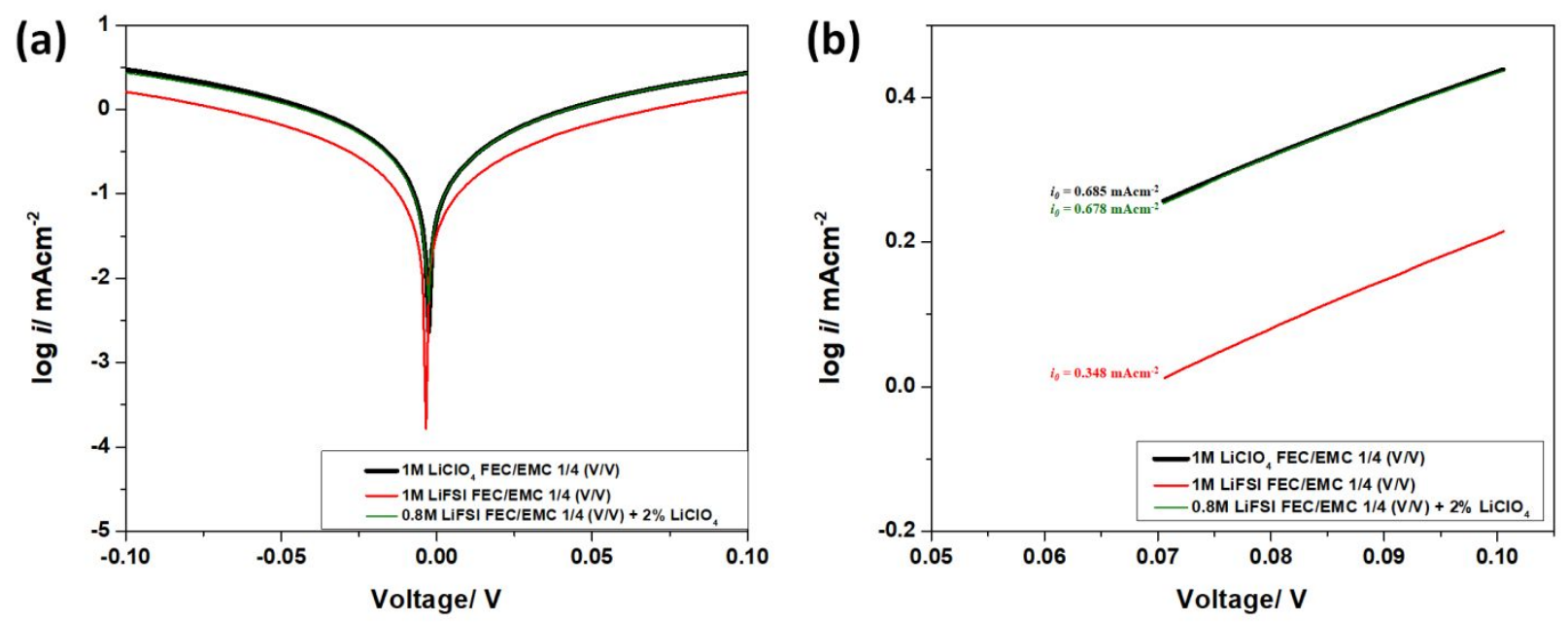

Figure S7. (a) Tafel plots obtained from CV test in Li/Cu cell with various FEC/EMC electrolytes. (b) The fitted Tafel plots obtained from CV measurements in Li/Cu cells using FEC/EMC electrolytes with a scan rate of $1.0 \mathrm{mV} / \mathrm{s}$. 

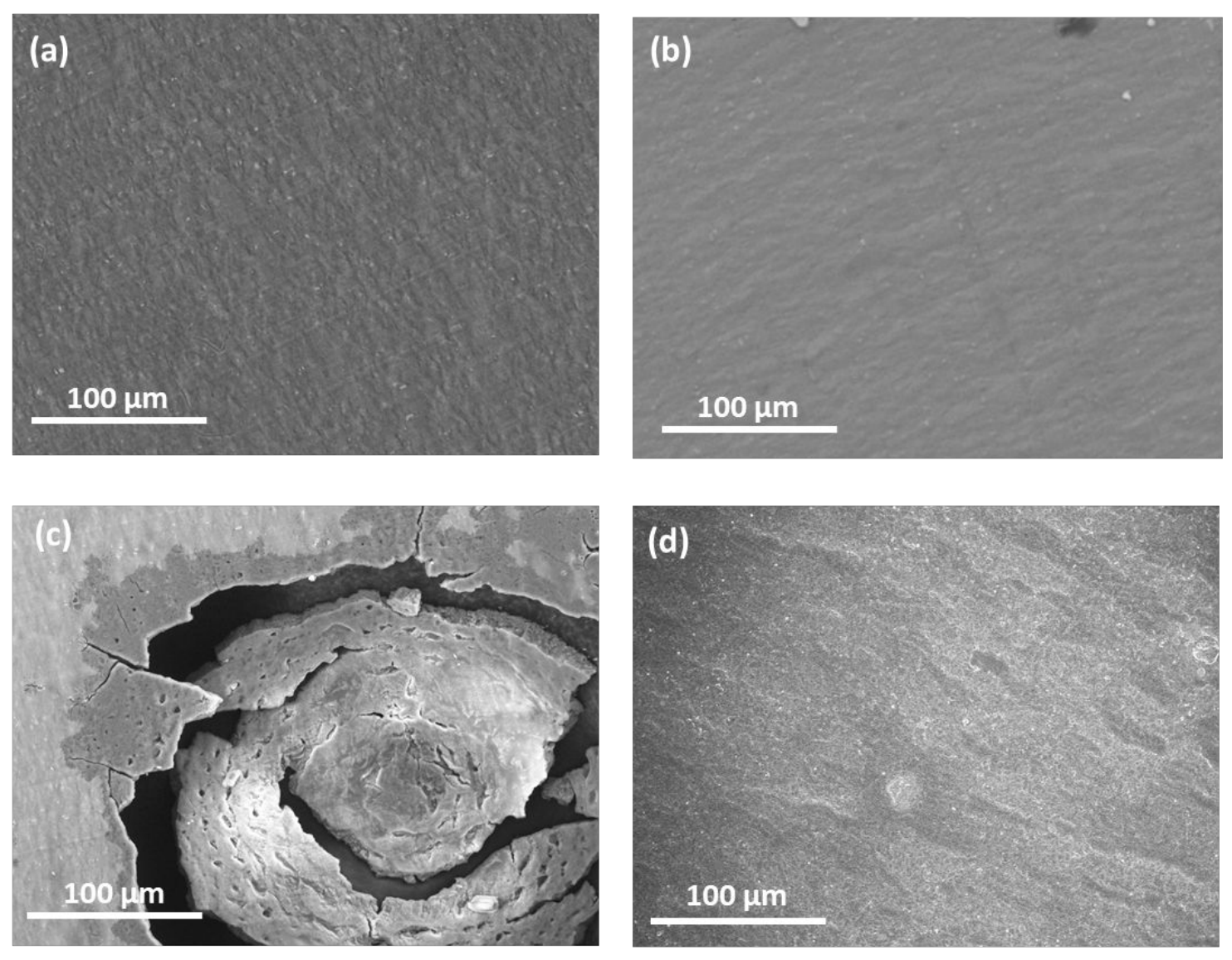

Figure S8. SEM image of Al working electrode before and after potentiostatic hold under different electrolytes. (a) pristine Al; (b) harvested from $1 \mathrm{M} \mathrm{LiClO}_{4}$ in $\mathrm{FEC} / \mathrm{EMC}=1 / 4(\mathrm{v} / \mathrm{v})$ electrolyte; (c) harvested from 1M LiFSI in FEC/EMC=1/4 (v/v) electrolyte; (d) harvested from $0.8 \mathrm{M} \mathrm{LiFSI}$ in $\mathrm{FEC} / \mathrm{EMC}=1 / 4(\mathrm{v} / \mathrm{v})$ with $2 \mathrm{wt} \% \mathrm{LiClO}_{4}$ additive electrolyte. 
Table S1. Li/NMC battery capacity retention and drop rate with different electrolyte formulations.

\begin{tabular}{|c|c|c|c|c|c|c|c|}
\hline \multirow{2}{*}{ Figure } & \multicolumn{3}{|c|}{ Battery design } & \multicolumn{2}{|c|}{$\begin{array}{c}\text { Estimated energy } \\
\text { density }\end{array}$} & \multirow{2}{*}{$\begin{array}{c}\text { Cycle numbers to take } \\
\text { from } 90 \% \text { retention to } \\
70 \% \text { retention }\end{array}$} & \multirow{2}{*}{$\begin{array}{l}\text { Cycle number } \\
\text { reaches } 70 \% \\
\text { capacity retention }\end{array}$} \\
\hline & $\begin{array}{c}\text { Anode } \\
\text { thickness }\end{array}$ & $\begin{array}{l}\text { Cathode } \\
\text { loading }\end{array}$ & $\begin{array}{c}\text { Electrolyte } \\
\text { formulation }\end{array}$ & Volumetric & Grammatic & & \\
\hline $1 a$ & $200 \mu \mathrm{m}$ & $2 \mathrm{mAh} / \mathrm{cm}^{2}$ & $\begin{array}{c}40 \mu \mathrm{L} 1.2 \mathrm{M} \mathrm{LiPF} \\
\text { in } \mathrm{EC} / \mathrm{EMC}=3 / 7 \\
\text { (wt.) }\end{array}$ & $220 \mathrm{Wh} / \mathrm{L}$ & $250 \mathrm{Wh} / \mathrm{kg}$ & 45 & $100^{\text {th }}$ \\
\hline $1 a$ & $20 \mu \mathrm{m}$ & $4.5 \mathrm{mAh} / \mathrm{cm}^{2}$ & $\begin{array}{c}20 \mu \mathrm{L} 1.2 \mathrm{M} \mathrm{LiPF} 6 \\
\text { in EC/EMC }=3 / 7 \\
\text { (wt.) }\end{array}$ & $1100 \mathrm{Wh} / \mathrm{L}$ & $450 \mathrm{Wh} / \mathrm{kg}$ & 5 & $16^{\text {th }}$ \\
\hline $1 b$ & $200 \mu \mathrm{m}$ & $2 \mathrm{mAh} / \mathrm{cm}^{2}$ & $\begin{array}{l}40 \mu \mathrm{L} 1 \mathrm{M} \mathrm{LiPF}_{6} \text { in } \\
\mathrm{FEC} / \mathrm{EMC}=1 / 4(\mathrm{v})\end{array}$ & $220 \mathrm{Wh} / \mathrm{L}$ & $250 \mathrm{Wh} / \mathrm{kg}$ & 102 & $270^{\text {th }}$ \\
\hline $1 b$ & $20 \mu \mathrm{m}$ & $4.5 \mathrm{mAh} / \mathrm{cm}^{2}$ & $\begin{array}{l}20 \mu \mathrm{L} 1 \mathrm{M} \mathrm{LiPF}_{6} \text { in } \\
\mathrm{FEC} / \mathrm{EMC}=1 / 4(\mathrm{v})\end{array}$ & $1100 \mathrm{Wh} / \mathrm{L}$ & $450 \mathrm{Wh} / \mathrm{kg}$ & 7 & $45^{\text {th }}$ \\
\hline $1 c$ & $20 \mu \mathrm{m}$ & $4.5 \mathrm{mAh} / \mathrm{cm}^{2}$ & $\begin{array}{l}20 \mu \mathrm{L} 1 \mathrm{M} \mathrm{LiPF}_{6} \text { in } \\
\mathrm{FEC} / \mathrm{EMC}=1 / 4(\mathrm{v})\end{array}$ & $1100 \mathrm{Wh} / \mathrm{L}$ & $450 \mathrm{Wh} / \mathrm{kg}$ & 7 & $45^{\text {th }}$ \\
\hline $1 c$ & $40 \mu \mathrm{m}$ & $4.5 \mathrm{mAh} / \mathrm{cm}^{2}$ & $\begin{array}{l}20 \mu \mathrm{L} 1 \mathrm{M} \mathrm{LiPF}_{6} \text { in } \\
\mathrm{FEC} / \mathrm{EMC}=1 / 4(\mathrm{v})\end{array}$ & $800 \mathrm{Wh} / \mathrm{L}$ & $400 \mathrm{Wh} / \mathrm{kg}$ & 15 & $52^{\text {th }}$ \\
\hline $1 c$ & $60 \mu \mathrm{m}$ & $4.5 \mathrm{mAh} / \mathrm{cm}^{2}$ & $\begin{array}{l}20 \mu \mathrm{L} 1 \mathrm{M} \mathrm{LiPF}_{6} \text { in } \\
\mathrm{FEC} / \mathrm{EMC}=1 / 4(\mathrm{v})\end{array}$ & $600 \mathrm{Wh} / \mathrm{L}$ & $380 \mathrm{Wh} / \mathrm{kg}$ & 6 & $63^{\text {th }}$ \\
\hline $1 d$ & $60 \mu \mathrm{m}$ & $4.5 \mathrm{mAh} / \mathrm{cm}^{2}$ & $\begin{array}{l}20 \mu \mathrm{L} 1 \mathrm{M} \mathrm{LiPF}_{6} \text { in } \\
\mathrm{FEC} / \mathrm{EMC}=1 / 4(\mathrm{v})\end{array}$ & $600 \mathrm{Wh} / \mathrm{L}$ & $380 \mathrm{Wh} / \mathrm{kg}$ & 6 & $63^{\text {th }}$ \\
\hline $1 d$ & $60 \mu \mathrm{m}$ & $4.5 \mathrm{mAh} / \mathrm{cm}^{2}$ & $\begin{array}{l}30 \mu \mathrm{L} 1 \mathrm{M} \mathrm{LiPF}_{6} \text { in } \\
\mathrm{FEC} / \mathrm{EMC}=1 / 4(\mathrm{v})\end{array}$ & $600 \mathrm{Wh} / \mathrm{L}$ & $350 \mathrm{Wh} / \mathrm{kg}$ & 5 & $90^{\text {th }}$ \\
\hline $1 d$ & $60 \mu \mathrm{m}$ & $4.5 \mathrm{mAh} / \mathrm{cm}^{2}$ & $\begin{array}{l}40 \mu \mathrm{L} 1 \mathrm{M} \mathrm{LiPF}_{6} \text { in } \\
\mathrm{FEC} / \mathrm{EMC}=1 / 4(\mathrm{v})\end{array}$ & $600 \mathrm{Wh} / \mathrm{L}$ & $330 \mathrm{Wh} / \mathrm{kg}$ & 9 & $112^{\text {th }}$ \\
\hline
\end{tabular}

Table S2. Fitted VFT empirical equation results.

\begin{tabular}{llll}
\hline Electrolyte (FEC/EMC) & $\boldsymbol{B}(\mathrm{K})$ & $\boldsymbol{\sigma}_{\mathbf{0}}(\mathbf{m S} / \mathbf{c m})$ & $\boldsymbol{T}_{\mathbf{0}}(\mathrm{K})$ \\
\hline $\mathbf{1 M ~ L i F S I}$ & 217 & 59.7 & 167 \\
$\mathbf{1 M ~ \text { LiClO } _ { 4 }}$ & 226 & 19.5 & 153 \\
& 251 & 27.8 & 166 \\
\hline
\end{tabular}


Table S3. Li/NMC battery capacity retention and drop rate with different electrolyte formulations.

\begin{tabular}{|c|c|c|c|c|}
\hline Electrolyte & 1st CE & $\begin{array}{c}\text { Capacity after } \\
\text { formation }(\mathrm{mAh} / \mathrm{g})\end{array}$ & $\begin{array}{c}\text { Cycle number to } \\
\text { take from } 90 \% \\
\text { retention to } 70 \% \\
\text { retention }\end{array}$ & $\begin{array}{l}\text { Cycle number on } \\
70 \% \text { capacity } \\
\text { retention }\end{array}$ \\
\hline $\begin{array}{r}1 \mathrm{M} \mathrm{LiBF} \text { in } \\
\mathrm{FEC} / \mathrm{EMC}=3 / 7(\mathrm{v})\end{array}$ & $89.6 \%$ & 181 & 1 & $5^{\text {th }}$ \\
\hline $\begin{array}{r}1 \mathrm{M} \mathrm{LiPF} \text { in } \\
\text { FEC/EMC=1/4 (v) }\end{array}$ & $89.8 \%$ & 179 & 3 & $49^{\text {th }}$ \\
\hline $\begin{array}{r}1 \mathrm{M} \mathrm{LiClO}{ }_{4} \text { in } \\
\text { FEC/EMC }=3 / 7(\mathrm{v})\end{array}$ & $90.1 \%$ & 177 & 55 & $126^{\text {th }}$ \\
\hline $\begin{array}{r}1 \mathrm{M} \text { LiFSI in } \\
\text { FEC/EMC=3/7 (v) }\end{array}$ & $90.2 \%$ & 182 & 14 & $147^{\text {th }}$ \\
\hline
\end{tabular}

Table S4. The average 10-cycle Coulombic efficiency for Li/Cu cells employing $1 \mathrm{M}$ $\mathrm{LiClO}_{4} \mathrm{FEC} / E M C=1 / 4,1 \mathrm{M} \mathrm{LiFSI} \mathrm{FEC/EMC}=1 / 4$, and $0.8 \mathrm{M} \mathrm{LiFSI} \mathrm{FEC/EMC=1/4} \mathrm{with} 2 \%$ $\mathrm{LiClO}_{4}$ electrolytes.

\begin{tabular}{cc}
\hline Electrolyte & $\begin{array}{c}\text { Average 10-cycle } \\
\text { Coulombic efficiency }\end{array}$ \\
\hline $1 \mathrm{M} \mathrm{LiClO}_{4} \mathrm{FEC} / \mathrm{EMC}=1 / 4$ & $97.82 \%$ \\
$1 \mathrm{M} \mathrm{LiFSI} \mathrm{FEC/EMC=1/4}$ & $98.30 \%$ \\
$\begin{array}{c}\text { 0.8M LiFSI FEC/EMC=1/4 } \\
\text { with } 2 \% \mathrm{LiClO}_{4}\end{array}$ & $98.65 \%$ \\
\hline
\end{tabular}

Table S5. The amounts of FEC and EMC in the Li/NMC622 cells after 70 cycles.

\begin{tabular}{ccc}
\hline Electrolyte & $\mathrm{FEC} / \mathrm{mg}$ & $\mathrm{EMC} / \mathrm{mg}$ \\
\hline 1M LiFSI FEC/EMC 1/4 (V/V) & 3.6 & 8.4
\end{tabular}


Table S6. Li/NMC battery capacity retention and drop rate with different electrolyte formulations.

\begin{tabular}{|c|c|c|c|c|}
\hline Electrolyte & 1st CE & $\begin{array}{c}\text { Specific } \\
\text { capacity after } \\
\text { formation } \\
(\mathrm{mAh} / \mathrm{g})\end{array}$ & $\begin{array}{l}\text { Cycle number to } \\
\text { take from } 90 \% \\
\text { retention to } \\
70 \% \text { retention }\end{array}$ & $\begin{array}{l}\text { Cycle number on } \\
70 \% \text { capacity } \\
\text { retention }\end{array}$ \\
\hline $\begin{array}{r}1 \mathrm{M} \mathrm{LiClO} \text { in }_{4} \\
\mathrm{FEC} / \mathrm{EMC}=1 / 4(\mathrm{v} / \mathrm{v})\end{array}$ & $90.1 \%$ & 184.5 & 55 & $126^{\text {th }}$ \\
\hline $\begin{array}{r}1 \mathrm{M} \text { LiFSI in } \\
\mathrm{FEC} / \mathrm{EMC}=1 / 4(\mathrm{v} / \mathrm{v})\end{array}$ & $89.8 \%$ & 184.9 & 14 & $147^{\text {th }}$ \\
\hline $\begin{array}{l}\quad 0.8 \mathrm{M} \mathrm{LiFSI} \text { in } \\
\text { FEC/EMC=1/4 (v/v) +2 } \\
\text { wt. \% } \mathrm{LiClO}_{4}\end{array}$ & $90.1 \%$ & 185.7 & 76 & $222^{\text {th }}$ \\
\hline
\end{tabular}

